\title{
Message from a long-time friend: congratulations on Emeritus Professor Satoshi Ōmura's accomplishments
}

The Journal of Antibiotics (2017) 70, 551-552; doi:10.1038/ja.2017.43

This issue is dedicated to Professor Ōmura in honor of his long and unequalled service to this Journal and in celebration of his being awarded a 2015 Nobel Prize for Physiology or Medicine. Satoshi delivered the most scientific, lucid and well-illustrated Nobel lecture of those given in Stockholm last year (I attended all nine). This prize, recognized world-wide as the highest award in this field of science, is a fitting crown to a lifetime of devotion and achievement, which by every indication is not yet finished.

Satoshi Ōmura was born in Nirasaki, Yamanashi Prefecture on 12 July 1935 . He graduated with a Bachelor's degree from Yamanashi University in 1958 and taught science and physical education at the high school level while studying for a Master's degree, which he received in 1963 . He was a teaching assistant at Yamanashi University before he joined the Kitasato Institute in 1965. In his early career, he was giving evening lectures in chemistry and one of his students who worked during the day as a mechanic would come to the lectures straight from work still in his greasy clothes. Rather than be offended by this, Satoshi tells how he was inspired by the student's dedication and this led to his greater commitment and hard work. It is difficult to imagine that Professor Ōmura could have worked any harder than he did over the next 50+ years. He completed his formal academic training with a $\mathrm{PhD}$ in Pharmaceutical Science at the University of Tokyo (1968) and a $\mathrm{PhD}$ in Chemistry at Tokyo University of Science (1970). At the Kitasato Institute and Kitasato University he rose through the ranks from Researcher to President by 1990 . He is currently Distinguished Emeritus Professor and Special Coordinator of the Project for Drug Discovery. In 1971, Professor Ōmura took a sabbatical in Connecticut with the late
Professor Max Tishler at Wesleyan University, which in 2005 awarded him an honorary Doctor of Science and appointed him as the first Max Tishler Professor of Chemistry.

There are so many facets to this great man that it is not possible to do justice to him in a simple editorial. $\mathrm{He}$ is an incredibly broad-based scientist, an artist, a golfer and a cross-country skier, a devoted family man, a teacher and a mentor of many scientists. His science covers almost every discipline related to drug discovery, with a concentration on microbes from their genetics, taxonomy, physiology and secondary metabolites. Although he has concentrated on actinomycetes, other bacteria and fungi have not been ignored. An indication of the breadth of his drug-discovery science is the development of an erythromycin derivative to capitalize on an adverse effect of the parent, by removing the antibacterial activity and accentuating the motilin agonist activity to obtain an agent that would reactivate peristalsis following gastrointestinal surgery. Early on he realized that rare and unusual microbes were an optimal source of novel antibiotics and this approach led to the discovery of 13 new genera and 42 new species of actinomycetes. He also realized that to capitalize on novel secondary metabolites one had to test broadly for bioactivity, and although he did that at the Kitasato Institute, he also sought collaborators who could extend that testing. The collaboration with Merck led to the discovery of the nematocidal activity of avermectins in an in vivo assay, a mouse infected with Nematospiroides dubius. Satoshi had personally collected, from beside a golf course in Kawana, the soil, from which the source of these antibiotics was isolated, a novel Streptomyces species. Even his non-scientific interests interacted with his science. Professor Ōmura's willingness to undertake collaborative efforts world-wide also led to the first genetically engineered novel antibiotics, the mederrhodins (1986) in collaboration with Dr David Hopwood (now Sir David) from the John Innes Institute in the UK.

Professor Ōmura and Merck donate ivermectin (22,23-dihydroavermectin Bla \& $\mathrm{B} 1 \mathrm{~b})$ to the WHO for use against the human diseases, onchocercaisis and filariasis (river blindness and elephantiasis, respectively), where the goal is to eliminate both of these diseases by 2020 . However, ivermectin is a billion-dollar product for veterinary and agricultural use. Professor Ōmura has used the royalties from this to build, first a teaching hospital in Kitamoto at the outskirts of Tokyo, and then an Art museum in Nirasaki. Both of these buildings are lined with art, either donated directly by Satoshi or by artists who know and appreciate this artist. His comment with respect to the hospital is that it aims to administer to both the physical and spiritual health of the patients. The Ōmura Nirasaki Museum is devoted to female artists, an example of Professor Ōmura's modern commitment to equality and diversity. As well as his current professorships at the Kitasato and Wesleyan Universities, he is also President of Joshibi University of Art and Design.

In his search for new drugs from microbes Professor Ōmura has discovered over 480 novel secondary metabolites, published over 1100 scientific articles and been cited more than 25000 times. As this issue will define, his service to The Journal of Antibiotics is without equal; he has been on the Editorial Board since 1973 and Editor-in-Chief from 2005 (Emeritus from 2014).

Despite his unequalled achievements and honors, Professor Ōmura is a surprisingly modest man, he is the absolute epitome of a 
'scholar and a gentleman', always generous and willing to help conscientious young scientists and to assist in any way in the development of science. The essay, entitled 'Snow on Red Plum Blossoms' he wrote following the disastrous tsunami of 2011 is incredibly beautiful, both in its content and in its insight into his soul. I am incredibly honored to call him my colleague and friend. For my 75th birthday my wife, Anne, wrote to our family and contacts in my e-mail accounts asking for contributions for a book she was assembling as a gift for me. Professor Ōmura wrote a two-page account of our interactions over 40 years including a photo of us taken in 1990. This is one of my most prized treasures.

We all celebrate this great man's achievements and bask in the glow of the results of his hard work.

\section{CONFLICT OF INTEREST}

The authors declare no conflict of interest.

James B McAlpine

Department of Medicinal Chemistry and Pharmacognosy, College of Pharmacy, University of Illinois at Chicago, Chicago, IL, USA E-mail: mcalpine@uic.edu 